\title{
Effect of organic and inorganic sources of nutrients on performance of clitoria grown in stressed environment
}

\begin{abstract}
Arid lands characterized by harsh environments viz. high temperature, limited water, salinity and all adverse conditions for plant production. The excessive use of chemical fertilizers aggravated the problem. The objective of this research was to look into organic fertilizers as soil amendment and nutrients supplier in such stressed environment. The treatments consisted of farmyard manure and chicken manures applied separately and in combination with each other, in addition to NPK and a control for comparison purposes. Test crop was Clitoria ternate (leguminous forage). Treatments consisted of a fermented chicken and cow manures applied separately and in combination plus NPK fertilizer and a control laid in a randomized complete block design. Results showed that organic fertilizers (poultry and cow manures) are more effective in increasing nodulation, productivity and improving forage quality of Clitoria ternate L. than inorganic fertilizer (NPK) under adverse conditions of salinity in arid lands. Poultry manure increased forage fresh and dry productivity over the control by $145 \%$ and $137 \%$, respectively and the differences were significant $(\mathrm{P} \leq 0.05)$. Fermented organic fertilizers increased nodulation, yield and quality of Clitoria ternate Compared to inorganic (NPK) fertilizers in an arid saline environment of western Saudi Arabia.
\end{abstract}

Keywords: bio fertilizers, clitoria ternate, inorganic fertilizers, leguminous forages, salinity, seed pelleting
Volume 6 Issue I - 2017

\author{
Awad O Abusuwar, Fahad Alghabari \\ Department of Arid Land Agriculture, Faculty of Meteorology, \\ Saudi Arabia
}

\begin{abstract}
Correspondence: Awad O Abusuwar, Department of Arid Land Agriculture, Faculty of Meteorology Environment \& Arid Land Agriculture, King Abdulaziz University, Jeddah: 2 1589, Saudi Arabia,Tel +966-564-900-736, Email aabusuwar@kau.edu.sa
\end{abstract}

Received: October 13,2017 | Published: January 27, 2017

\section{Introduction}

Arid lands characterized with fragile ecosystems, low land productivity, limited good quality irrigation water and non-sustainable farming systems. The Kingdom of Saudi Arabia entirely lies within arid land with an annual rainfall ranging from 00 to $100 \mathrm{~mm} /$ annum. This limited rainfall coupled with high evaporation so the cultivable pockets in valleys of the western region, which mostly depends on saline irrigation, become more saline. According to Ventorinoet al., ${ }^{1}$ the saline and harsh climatic condition hinder survival of Rhizobium spp, therefore, leguminous crops like Clitoria cannot form effective nodules to assist in nitrogen provision to the crop.

Organic farming has become one of the fastest growing segments of agriculture throughout the world because in conventional agriculture system use of chemicals has worried people about food quality, sustainability and other environmental consequences while organic agriculture assures high-quality food, sustainability and protect the environment. ${ }^{2}$ Saudi Arabia has low soil organic matter in spite that it is well known that enrichment of organic matter reduce salinity effect and increase moisture conservation and as result stimulates crop growth and quality.,4 The use of organic fertilizers, particularly poultry and farmyard manures, are known to benefit soils under such adverse environment through improving soil physical and chemical properties, thereby enhancing crop productivity. ${ }^{5}$ Several researchers pointed out that organic manure help in conserving cropping systems through recycling of nutrients. ${ }^{6,7}$ Moreover, Khan et al., ${ }^{8}$ reported that addition of organic manures with crop residues led to an increase in available phosphorus in soil in comparison to the control. On the other hand, the use of inorganic fertilizers, particularly under saline condition, has not been helpful and is often associated with reduced crop yield, cause soil acidity and nutrient imbalances. ${ }^{9,10}$

The aim of this research was to evaluate the effects of addition of farmyard manure and chicken manure alone and in combination with each other as seed pellets to serve as soil conditioner and nutrient suppliers in a saline arid site compared to inorganic (NPK) fertilizer at Hada Al-Sham Experimental Research Station of King Abdulaziz University.

\section{Materials and methods}

An experiment was conducted at Hada Al-Sham Research Station over two successive seasons during 2015/16. The experiment included a forage legume (Clitoria ternate L.) as a test crop. The treatments consisted of:

i. Fermented cow manure applied at a rate of 5 tons/ha- denoted as $\mathrm{CM}$

ii. Fermented Poultry manure applied at a rate of 5 tons/ha- denoted as PM

iii. Fermented poultry and cow manure combined at a rate of 2.5 tons/ ha of each -this is denoted as $1 / 2 \mathrm{PMCM}$

iv. NPK applied at a rate of $50 \mathrm{~kg} / \mathrm{ha}$ - denoted as NPK

v. Control-no fertilizers added denoted as $\mathrm{C}$

The poultry and cow manures were fermented for six weeks before 
use to illuminate all weed seeds and pathogens present in the manure. Thereafter, it was incorporated into soil before planting. In addition, seeds were pelleted with the manure according to treatments.

Rhizobium strain specific to Clitoria was inoculated to seeds before planting during the seed pelleting process. This was done by mixing gum Arabic powder with the strain of bacteria, fermented manure and seeds immediately before planting.

The following growth and yield parameters were taken during the course of the study:

\section{Leaf area}

Leaf area was determined three times (at $2^{\text {nd }}, 4^{\text {th }}$ and $6^{\text {th }}$ cut) during the study period using plant canopy analyzer, Model LAI-2270 manufactured by Li-cor Biosciences, USA.

\section{Forage fresh and dry yields}

The entire plot (3 Sq.m) was harvested and weighed to get forage fresh yield, whereas a sample was taken from each plot, oven dried to obtain dry yields. Both fresh and dry yields were transformed from $\mathrm{kg} / \mathrm{ha}$ into tons/ha.

\section{Forage nutritive value}

Proximate analysis for plant tissues to determine the nutritive value of the forages was performed according to AOAC (1990). NDF, $\mathrm{ADF}$ and cellulose were determined by the method of Goering et al. ${ }^{11}$ Total carotenoids were extracted and quantified as described by Quackenbush et al. ${ }^{12}$

\section{Nodulation}

Two month after planting, random samples were taken from each treatment by carefully uprooting plants to examine total number and effective number of nodules per plant produced. Effective nodules were determined by microscopic examination to look for the red pigment (leg hemoglobin) if present or not as its presence indicates its effectiveness in nitrogen fixation.

\section{Experimental design and data analysis}

A randomized complete block design (RCBD) was used and analysis of variance (ANOVA) was performed on data according to Steel et al..$^{13}$ Means of treatments were separated according to the LSD method.

\section{Results and discussion}

\section{Leaf area}

Leaf area, which was measured three times (2nd cut, 4th cut and 6th cut) during the course of the study, showed significant $(\mathrm{P} \leq 0.05)$ differences between treatments (Table 1). Organic manures (poultry and Cow manures) were always superior over the inorganic NPK fertilizer and the control throughout the three sampling dates. The ranking order for the treatments was $\mathrm{PM}>\mathrm{CM}>\mathrm{PM}+\mathrm{CM}>\mathrm{NPK}$ $>$ Control. Analysis of fermented poultry and cow manures showed that poultry manure contained three folds nutrients more than cow manures although cow manure was more effective in improving soil physical characteristics compared to poultry manure. ${ }^{14}$ Moreover, addition of inorganic fertilizers to saline soils will add more to soil solutes, which depresses plant uptake of water and causes nutrients imbalances. ${ }^{9,10}$

\section{Fresh and dry forage yields}

Fresh and dry forage yields are presented in Tables 2, Table 3, respectively. Significant differences $(\mathrm{P} \leq 0.05)$ were detected between treatments for both parameters. Poultry manure led to an increase in forage productivity both in fresh and dry matter. It increased fresh yield by $145 \%$ over the control for the seven cuts. Corresponding increment for dry matter for the same treatments was $137 \%$. As was noticed for results of leaf area, the same trend was repeated in forage productivity rankings. The ranking order for productivity both for fresh and dry matter yields were $\mathrm{PM}>\mathrm{CM}>\mathrm{PM}+\mathrm{CM}>\mathrm{NPK}>$ Control. Poultry and cow manures applied separately or in combinations improved forage productivity in comparison to inorganic (NPK) manure. Since leaf area was improved by organic manures, it was expected to have this reflected in forage productivity as leaf area is one of the components contributing to productivity and the quality of the forage.

The chemical analysis of the experimental site soil indicates its salinity and irrigation water analysis showed that it contained 3500 TDS (ppm) which were enough to depress plant growth. The application of organic manures (poultry and cow manures) might have mitigated the negative effects of salinity on growth through improvement of soil physical properties to allow salts go below rooting zone of the crop. ${ }^{9,10}$

In addition, the nutrients supplied by the manures might have positively affected plant growth. ${ }^{4,9,14}$ It is to be mentioned that poultry manure contained three folds nutrients compared to cow manures. ${ }^{15}$ It is well documented that organic manures have great beneficial effects on soil physical and chemical properties plus supplying nutrients to plants. ${ }^{9,10,14}$ This was especially true in case of the studied site where the soil is poor and known for low productivity. Reports showed that farmyard manure increased forage sorghum yield four times compared to the control in a saline-sodic soil in the Sudan. ${ }^{5}$

\section{Proximate analysis}

Forage nutritive value (quality) expressed in $\mathrm{CP}, \mathrm{CF}, \mathrm{NDF}, \mathrm{ADF}$, cellulose and carotenoids percent is presented in Table 4. Significant $(\mathrm{P} \leq 0.05)$ differences were detected between treatments. Higher $\mathrm{CP}$ and carotenoids and lower $\mathrm{CF}, \mathrm{NDF}, \mathrm{ADF}$, ether extract and cellulose were reported for the poultry manure treatments in comparison to other treatments indicating the improvement in forage quality. Total carotenoids concentration is known to decrease rapidly with plant age $^{16}$ and stress environment, like salinity, may have a negative effect too. Berthelsen ${ }^{17}$ concluded that carotene assists in increasing conception rates.

The organic fertilizer (poultry and cow manures) treatments significantly improved forage quality in terms of nutrients. Organic materials, besides improving soil physical properties, supply plants with nutrients especially under saline conditions. This is in line with the results reported by Abusuwar et al. ${ }^{5}$ and Ayoola et al. ${ }^{10}$

\section{Nodulation}

Total and effective number of nodules per plant is presented in Table 5. Significant differences $(\mathrm{P} \leq 0.05)$ were reported for total and effective number of nodules per plant among all treatments. Poultry 
manure applied alone (PM) or in combination with Cow manure $(\mathrm{PM}+\mathrm{CM})$ significantly outscored other treatments both in total and effective number of nodules per plant. The least number of nodules per plant (total and effective) was reported for the control followed by the NPK treatment. The poultry manure treatment produced $566 \%$ more nodules compared to the control and $300 \%$ more than the NPK treatment.

Table I Effect of treatments on leaf area of Clitoria (Sq.cm.)
It is worth mentioning that the control treatment, unlike other treatments, produced no effective nodules. It is known that salinity and soil $\mathrm{pH}$ in general affects Rhizobium growth and consequently forage productivity as seen in forage fresh and dry yields presented in Tables 2 and Table 3, respectively. Both organic manures improved soil physical and chemical properties especially in saline soils to mitigate their harmful effects on growth. ${ }^{18,19}$

\begin{tabular}{llll}
\hline Sampling date & 2nd cut & 4th cut & 6th cut \\
\hline Treatments & & & \\
\hline Control & $3.40 \mathrm{c}$ & $4.42 \mathrm{~b}$ & $4.43 \mathrm{~b}$ \\
$\mathrm{CM}$ & $7.22 \mathrm{a}$ & $6.17 \mathrm{a}$ & $6.17 \mathrm{a}$ \\
$\mathrm{Pm}$ & $7.27 \mathrm{a}$ & $6.80 \mathrm{a}$ & $6.79 \mathrm{a}$ \\
$\mathrm{PM}+\mathrm{CM}$ & $6.20 \mathrm{ab}$ & $5.20 \mathrm{~b}$ & $5.18 \mathrm{~b}$ \\
$\mathrm{NPK}$ & $5.15 \mathrm{~b}$ & $4.62 \mathrm{~b}$ & $4.61 \mathrm{~b}$ \\
LSD 0.05 & 1.19 & 0.95 & 0.93 \\
$\mathrm{CV}$ & 13.21 & 11.4 & 11.2
\end{tabular}

$\mathrm{CM}$, cow manure; $\mathrm{Pm}$, poultry manure; $\mathrm{PM}+\mathrm{CM}$, mixture of both cow \& poultry manures

Table 2 Effect of treatments on fresh weight (tonlha)

\begin{tabular}{llllllll}
\hline Treatments & 1st cut & 2nd cut & 3rdcut & 4th cut & 5th cut & 6th cut & 7th cut \\
\hline Control & $2.95 \mathrm{~d}$ & $4.75 \mathrm{c}$ & $2.00 \mathrm{c}$ & $11.00 \mathrm{~d}$ & $13.00 \mathrm{c}$ & $12.85 \mathrm{c}$ & $17.10 \mathrm{~d}$ \\
$\mathrm{CM}$ & $9.95 \mathrm{ab}$ & $8,85 \mathrm{~b}$ & $4.75 \mathrm{~b}$ & $23.80 \mathrm{~b}$ & $22.65 \mathrm{ab}$ & $25.10 \mathrm{~b}$ & $27.25 \mathrm{ab}$ \\
$\mathrm{PM}$ & $13.25 \mathrm{a}$ & $12.50 \mathrm{a}$ & $8.10 \mathrm{a}$ & $32.00 \mathrm{a}$ & $24.35 \mathrm{a}$ & $34.10 \mathrm{a}$ & $29.60 \mathrm{a}$ \\
$\mathrm{CM}+\mathrm{PM}$ & $7.75 \mathrm{bc}$ & $7.25 \mathrm{bc}$ & $4.50 \mathrm{~b}$ & $18.60 \mathrm{bc}$ & $19.10 \mathrm{~b}$ & $20.10 \mathrm{bc}$ & $24.85 \mathrm{~b}$ \\
$\mathrm{NPK}$ & $5.30 \mathrm{~cd}$ & $5.35 \mathrm{c}$ & $2.60 \mathrm{bc}$ & $14.65 \mathrm{~cd}$ & $15.15 \mathrm{c}$ & $17.85 \mathrm{bc}$ & $19.85 \mathrm{c}$ \\
$\mathrm{LSD}$ & 4.05 & 3.2 & 2.25 & 6.35 & 3.9 & 8.95 & 2.45 \\
CV & 33.66 & 27.2 & 33.85 & 20.72 & 13.42 & 26.43 & 6.74 \\
\hline
\end{tabular}

$\mathrm{CM}$, cow manure; Pm, poultry manure; $\mathrm{PM}+\mathrm{CM}$, mixture of both cow \& poultry manures

Table 3 Effect of treatments on dry weight (tonlha)

\begin{tabular}{lccccccc}
\hline Treatments & 1st cut & 2nd cut & 3rdcut & 4th cut & 5th cut & 6th cut & 7th cut \\
\hline Control & $1.45 \mathrm{~b}$ & $1.90 \mathrm{c}$ & $1.10 \mathrm{c}$ & $6.75 \mathrm{~d}$ & $4.80 \mathrm{~d}$ & $2.15 \mathrm{~d}$ & $7.35 \mathrm{c}$ \\
$\mathrm{CM}$ & $3.05 \mathrm{~b}$ & $3.30 \mathrm{~b}$ & $2.80 \mathrm{~b}$ & $16.95 \mathrm{~b}$ & $8.55 \mathrm{~b}$ & $5.65 \mathrm{~b}$ & $11.20 \mathrm{ab}$ \\
$\mathrm{PM}$ & $6.80 \mathrm{a}$ & $5.20 \mathrm{a}$ & $5.00 \mathrm{a}$ & $23.30 \mathrm{a}$ & $10.00 \mathrm{a}$ & $7.60 \mathrm{a}$ & $11.80 \mathrm{a}$ \\
$\mathrm{CM}+\mathrm{PM}$ & $2.10 \mathrm{~b}$ & $3.15 \mathrm{~b}$ & $2.15 \mathrm{bc}$ & $13.85 \mathrm{bc}$ & $7.10 \mathrm{c}$ & $4.80 \mathrm{~b}$ & $10.55 \mathrm{~b}$ \\
$\mathrm{NPK}$ & $1.70 \mathrm{~b}$ & $2.55 \mathrm{bc}$ & $1.50 \mathrm{bc}$ & $10.10 \mathrm{~cd}$ & $5.55 \mathrm{~d}$ & $3.55 \mathrm{c}$ & $8.05 \mathrm{c}$ \\
$\mathrm{LSD}$ & 3.5 & 0.75 & 1.65 & 4.55 & 1.15 & 1.1 & 0.8 \\
$\mathrm{CV}$ & 17.01 & 15.72 & 14.36 & 20.81 & 10.48 & 15.18 & 5.58 \\
\hline
\end{tabular}

$\mathrm{CM}$, cow manure; $\mathrm{Pm}$, poultry manure; $\mathrm{PM}+\mathrm{CM}$, mixture of both cow \& poultry manures 
Table 4 Effect of treatments on proximate analysis

\begin{tabular}{llllllll}
\hline Treatments & $\mathbf{C P}(\%)$ & $\mathbf{C F}(\%)$ & $\mathbf{N D F}(\%)$ & $\mathbf{A D F}(\%)$ & Ether extract(\%) & Cellulose(\%) & Total carotenoids (mg/kg) \\
\hline Control & $17.0 \mathrm{e}$ & $31.0 \mathrm{a}$ & $54.21 \mathrm{a}$ & $45.50 \mathrm{a}$ & $4.80 \mathrm{a}$ & $29.30 \mathrm{a}$ & $310.23 \mathrm{e}$ \\
$\mathrm{CM}$ & $20.0 \mathrm{~b}$ & $28.5 \mathrm{~b}$ & $44.60 \mathrm{~d}$ & $42.40 \mathrm{c}$ & $4.35 \mathrm{~b}$ & $26.18 \mathrm{a}$ & $430.61 \mathrm{~b}$ \\
PM & $21.3 \mathrm{a}$ & $28.0 \mathrm{~b}$ & $42.65 \mathrm{e}$ & $34.80 \mathrm{~d}$ & $4.26 \mathrm{~b}$ & $21.22 \mathrm{~b}$ & $580.16 \mathrm{a}$ \\
CM+PM & $19.2 \mathrm{c}$ & $28.5 \mathrm{~b}$ & $48.30 \mathrm{c}$ & $43.80 \mathrm{ab}$ & $4.38 \mathrm{~b}$ & $28.10 \mathrm{a}$ & $399.21 \mathrm{c}$ \\
NPK & $18.2 \mathrm{~d}$ & $29.0 \mathrm{~b}$ & $50.20 \mathrm{~b}$ & $44.10 \mathrm{a}$ & $4.46 \mathrm{~b}$ & $28.50 \mathrm{a}$ & $330.50 \mathrm{~d}$ \\
LSD & 0.7 & 0.9 & 1.8 & 1.5 & 0.33 & 3.5 & 30.17 \\
CV & 12.05 & 14.7 & 14.28 & 9.15 & 8.13 & 12.87 & 16.85 \\
\hline
\end{tabular}

$\mathrm{CM}$, cow manure; $\mathrm{Pm}$, poultry manure; $\mathrm{PM}+\mathrm{CM}$, mixture of both cow \& poultry manures

Table 5 Effect of treatments on nodulation of Clitoria ternate

\begin{tabular}{lll}
\hline Treatments & Total number of Nodules & Effective Nodules \\
\hline Control & $3.0 \mathrm{~cd}$ & $0.0 \mathrm{~cd}$ \\
$\mathrm{CM}$ & $15.0 \mathrm{~b}$ & $13.0 \mathrm{~b}$ \\
$\mathrm{PM}$ & $20.0 \mathrm{a}$ & $19.0 \mathrm{a}$ \\
$\mathrm{CM}+\mathrm{PM}$ & $18.0 \mathrm{a}$ & $17.0 \mathrm{a}$ \\
$\mathrm{NPK}$ & $5.0 \mathrm{c}$ & $1.0 \mathrm{c}$ \\
LSD & 2.1 & 2.5 \\
$\mathrm{CV}$ & 13 & 14 \\
\hline
\end{tabular}

$\mathrm{CM}$, cow manure; $\mathrm{Pm}$, poultry manure; $\mathrm{PM}+\mathrm{CM}$, mixture of both cow \& poultry manures

\section{Conclusions}

It can be concluded from the results of this study that organic fertilizers (poultry and cow manures) are more effective in increasing nodulation, productivity and improving forage quality of Clitoria ternate L. than inorganic fertilizer (NPK) under adverse conditions of salinity in arid lands. Poultry manure increased forage fresh and dry productivity over the control by $145 \%$ and $137 \%$, respectively and the differences were significant $(\mathrm{P} \leq 0.05)$. Fermented organic fertilizers increased nodulation, yield and quality of Clitoria ternate Compared to inorganic (NPK) fertilizers in an arid saline environment of western Saudi Arabia.

\section{Acknowledgement}

This work was funded by the Deanship of Scientific Research (DSR), King Abdulaziz University, Jeddah under grant No. (155645-D-1435). The author, therefore, acknowledges with thanks DSR technical \& financial support.

\section{Conflict of interest}

The author declares no conflict of interest.

\section{References}

1. Ventorino V, Capotu R, De Pascale ES, et al. Response to salinity stress of Rhizobium leguminosarum bv. viciae strains in the presence of diffèrent légume host plants. Ann Micro. 2012;62:811-823.

2. Tredwel D, Riddle J, Barbercheck M, et al. What is OrganicFarming? Extension. 2011.
3. Daur I, Hassan G, Khan IA. Effect of different levels of nitrogen on dry matter and grain yield of faba bean (Vicia faba L.). Pak J Bot 2008;40:2453-2459.

4. Zirbin W, Faci JM, Aragues R. Mulching effects on moisture, temperature, structure and salinity of agricultural soils. Itea- Information Tech Eco Agric. 2011;107:148-162.

5. Abusuwar A O, El Zilal H. Effect of chicken manure on yield, quality and HCN concentration of two forage Sorghum (Sorghum bicolor L. Moench) cultivars. Agric Bio J North Amer. 2010;1:27-31.

6. Dominguez A, Bandana JC, Beckerb S, et al. Organic farming fosters agroecosystem functioning in Argentinean temperate soils:Evidence from litter decomposition and soil fauna. Appl Soil Eco. 2014;83:170-176.

7. Ze Ping Y, Sheng Xain Z, Jun L, et al. Effects of long-term winter planted green manure on distribution and storage of organic carbon and nitrogen in water-stable aggregates of reddish paddy soil under a double-rice cropping system. J Inter Agri. 2014;13:1772-1781.

8. Khan HZ, Malik MA, Saleem H. Effect of rate and source of organic material on the production potential of spring maize (Zea mays L.). Pak J Agri Sci. 2008;45:40-43.

9. Abusuwar AO, Bakhshawain A. Effect of different chemical fertilizers on seed yield and seed yield components of alfalfa grown under stress environment of western Saudi Arabia. Inter J Sci Nat. 2011;3:114-116.

10. Ayoola OT, Adeniyan ON. Influence of poultry manure and NPK on yield and yield components of crops under different cropping systems in southwest Nigeria. Afri J Biot. 2008;5:1386-1392.

11. Goering HK, Van PL. Forage fiber analysis (apparatus, reagents, procedures and some applications. Agricultural Hand Book No.379.US Department of Agriculture; 1970. 
12. Qauckenbush FW, Dyer MA, Smallidge RL. Analysis for carotenes and xanthophylls in dried plant materials. J Asso Offi Anal Chem. 1970;53:181-185.

13. Steel RGD, Torrie JH, Dicky DA. Principles and procedures of Statistics A biometric approach. 3rd ed. New York, USA: McGraw Hill; 1997.

14. Abusuwar AO, Daur I. Effect of poultry and cow manures on yield and quality of two cereal forages under natural saline condition of an arid land. Wulfenia J. 2014;21:209-212.

15. Daur I, Abusuwar A, Alghabari F. Exploitation of EM.1-treated blends of organic resources and humic acid for organic Berseem (Trifolium alexandrinumL.) production. Turk J Field Crops. 2015;20:125-130.
16. Barro C, Gonzalez G. Identification and estimation of carotenoids in lyophilized meals of four Vicia species at five different stages of growth. J Food Sci Agric. 1981;32:279-282.

17. Berthelsen A. Adding carotene appears to aid conception rates. Feedstuffs. $1982 ; 22: 11-12$

18. Faust S, Hanisch S, Burkert A, Joergensen R. Soil properties under manured Tamarindus indica in the Lithoral plain of South-Western Madagascar. Arid land Res Manage. 2014;29(2):167-179.

19. Mahmoud E, El-Gizawy E, Geries L. Effect of compost extract, nitrogen fixing bacteria and nitrogen level application on soil properties and onion crop. Arch Agron. 2015;61:185-201. 